\title{
Perspective of Economists and Extension Personnel towards Agricultural Subsidies in Punjab
}

\author{
Anupam Anand* and Manmeet Kaur \\ Department of Extension Education, Punjab Agricultural University, Ludhiana, Punjab, India \\ *Corresponding author: anupamanand1989@hotmail.com
}

\begin{abstract}
The subsidy is very important for growth of farmers in India. Many persons have presented their views on agriculture subsidies in national and international level through research papers and articles. The small and marginal farmers in India are poor and they depend on government support for cultivation of crops. In India, at present, centre as well as state governments are providing subsidies on fertilizers, irrigation, electricity and other subsidies to farmers and farmers' cooperative societies in the form of various inputs, crop insurance schemes and price support schemes etc. This study tries to bring forth the voice of agricultural economists and extension personnel who are closely involved with subsidies and matters related to them. The analysis was based on 20 economists and 20 extension personnel involved directly or indirectly with the issue of agricultural subsidies. This analysis can serve for providing a platform to voice the opinions of agricultural economists and extension personnel who are ignored most of the time during the policy framing related to subsidies in farming sector.

JEL classification: C82, Q13
\end{abstract}

Keywords: Agricultural subsidies, economists, extension personnel, perspective, Punjab

Agriculture subsidies in India were introduced to ensure equitable utilization of the resources for the people. Agricultural subsidies that encourage production and productivity have been widely criticized because of the cost of subsidies and that they are perceived to be far from uniformly distributed. There is a general view in academic, policy and political circles that agricultural subsidies are concentrated geographically, they are concentrated on relatively few crops and few producers and in many cases do not reach the targeted group(s) (Sharma \& Thaker 2009). It is also alleged that subsidies have a crowding-out effect on the farm investment, increasing fiscal deficits (Kaur 2012) and misuse of the financial resources (Mahadeva 2004). There is also widespread evidence that the more affluent farmers are able to garner a disproportionately large part of the subsidies (Swaminathan et al. 2013). The annual subsidy disbursement of the Government of India has increased dramatically in recent years (Gulati
\& Narayanan 2003). With large amounts being spent on subsidies, the Government is examining ways to ensure that this spending is carried out in ways that maximize positive outcomes, and lead to significant poverty reductions. Direct transfer of subsidies to address inefficiencies of present subsidy disbursement (whether as cash or otherwise) has dominated the debate in the public policy space for a considerable time (GOI 2011). The main reason why public investment in agriculture has declined is the deterioration in the fiscal position of the state governments and the tendency for politically popular but inefficient and even iniquitous subsidies to crowd out more productive investment. The economists in India and abroad have been contemplating since long on whether subsidies to the agricultural sector should continue or not. Moreover, if at all, subsidies have to be provided then which section of the society deserves it most. These scholars have attempted to analyse its pro and cons. The attempts were made 
to compare relative benefits of subsidies among rural vs. urban sector, small vs. large farmers, industry vs. agriculture and fertilizer vs. other farm input subsidies. The continuation of the subsidies for decentralized products and to support below poverty line consumers of the economy is strongly recommended by Dagli Committee Report (1979). It is pointed out that the marginal farmers having small farm holdings were being deprived of the benefit of subsidies for irrigation and agricultural inputs (Sinha \& Prasad 1982). Initial subsidies in credit, fertilizer, and irrigation helped farmers, especially the smallholders, to adopt the new technologies. But the small farms were often losers in the initial adoption stage of a new technology because the increased supply of agricultural products from large farms that have benefited from new technologies pushed the prices down (Fan et al. 2007). Some researchers assert to the extent that these subsidies should be withdrawn in a phased manner, such a step will reduce the fiscal deficit, improve the efficiency of resources use and increase funds for public investment in agriculture. On the other hand, there is a fear that agriculture production and income of farmers would decline if subsidies are curtailed (Kaur 2012).

\section{METHODOLOGY}

The study was conducted in three agro-climatic zones of Punjab viz. Central Plain zone, Western zone and Sub-Mountain Undulating zone and Punjab Agricultural University, Ludhiana. The three districts viz. Amritsar, Bathinda and Hoshiarpur were selected from central plain zone, western zone and sub-mountain undulating zone respectively on the basis that all the three districts had common agricultural schemes which provide subsidies on different inputs to the farmers. The selected agricultural schemes under which subsidies were provided to the farmers in Punjab are Rashtriya Krishi Vikas Yojana (RKVY), National Food Security Mission-Pulses (NFSM-Pulses), National Horticulture Mission (NHM), National Mission on Oilseeds and Oil Palm (NMOOP) and National Mission on Agricultural Extension and Technology (NMAET). 20 economists were selected randomly from the Department of Economics and Sociology of Punjab Agricultural University, Ludhiana. 20 extension personnel from the three selected districts were selected for this study on the basis of the criteria that these extension personnel were directly involved in the disbursement of the subsidies under the selected five schemes. The mean scores were calculated by giving a score of 3, 2 and 1 to Agree, Neutral and Disagree respectively. Similarly scores of 2 and 1 were assigned to Given and Withdrawn respectively. t-test was used to find out the significance of difference between the opinion and perceived impact of economists and extension personnel regarding agricultural subsidies.

$$
t=\frac{\bar{X}_{1}-\bar{X}_{2}}{S E}, S E=S p \sqrt{\frac{1}{n_{1}}+\frac{1}{n_{2}}}
$$

Where,

$$
\begin{aligned}
& X_{1}=\text { Mean of first sample } \\
& X_{2}=\text { Mean of second sample } \\
& n_{1}, n_{2}=\text { first and second sample population }
\end{aligned}
$$

Pooled estimate of sample standard deviation

$$
S p=\sqrt{\frac{\left(n_{1}-1\right) s_{1}^{2}+\left(n_{2}-1\right) s_{2}^{2}}{n_{1}+n_{2}-2}}
$$

Where,

$$
\begin{aligned}
& s_{1}{ }^{2}=\text { Variance of first sample } \\
& s_{2}{ }^{2}=\text { Variance of second sample }
\end{aligned}
$$

\section{RESULTS AND DISCUSSION}

\section{Opinion of the economists and extension personnel regarding different aspects of agricultural subsidies}

The findings of Table 1 revealed that all the economists as well as the extension personnel agreed that the subsidies supported the adoption of new technologies/practices. But highlighting the disparity between the large and small farmers, all the economists and extension personnel agreed that the large farmers with capacity to pay the electricity charges were getting more benefits from power subsidy rather than the small and marginal farmers All the economists felt that the subsidies are biased towards the large farmers while only 40 per cent of extension personnel held this opinion. All of the economists and two-third of the extension personnel that subsidies on the purchase of a machinery was 
Table 1: Distribution of the economists and extension personnel according to their opinion regarding agricultural subsidies

\begin{tabular}{|c|c|c|c|c|c|c|c|c|c|c|}
\hline \multirow[b]{2}{*}{$\begin{array}{l}\text { Sl. } \\
\text { No. }\end{array}$} & \multirow[b]{2}{*}{ Statements } & \multicolumn{4}{|c|}{ Economists $(n=20)$} & \multicolumn{4}{|c|}{ Extension Personnel $(\mathrm{n}=20)$} & \multirow[b]{2}{*}{$\mathrm{t}$-value } \\
\hline & & $\begin{array}{c}A \\
f(\%)\end{array}$ & $\begin{array}{c}N \\
f(\%)\end{array}$ & $\begin{array}{c}D \\
f(\%)\end{array}$ & MS & $\begin{array}{c}\text { A } \\
\mathrm{f}(\%)\end{array}$ & $\begin{array}{c}\mathrm{N} \\
\mathrm{f}(\%)\end{array}$ & $\begin{array}{l}D \\
f(\%)\end{array}$ & MS & \\
\hline 1 & Subsidies help to increase production. & $17(85)$ & $3(15)$ & - & 2.85 & $16(80)$ & $4(20)$ & - & 2.8 & 0.406 \\
\hline 2 & $\begin{array}{l}\text { Subsidies support the adoption of new } \\
\text { technologies or practices. }\end{array}$ & $20(100)$ & - & - & 3 & $20(100)$ & - & - & 3 & 0 \\
\hline 3 & $\begin{array}{l}\text { Subsidies are not responsible for making } \\
\text { producers more dependent on the } \\
\text { government. }\end{array}$ & - & $2(10)$ & $18(90)$ & 1.1 & - & $3(15)$ & $17(85)$ & 1.15 & 0.467 \\
\hline 4 & $\begin{array}{l}\text { Large farmers with capacity to pay the } \\
\text { electricity charges are getting more benefit } \\
\text { from power subsidy than the small and } \\
\text { marginal farmers }\end{array}$ & $20(100)$ & - & - & 3 & $20(100)$ & - & - & 3 & 0 \\
\hline 5 & $\begin{array}{l}\text { Farmers are ready to pay bills for irrigation } \\
\text { as uninterrupted and timely supply of } \\
\text { electricity is given for farming purposes. }\end{array}$ & $11(55)$ & $6(30)$ & $3(15)$ & 2.4 & $15(75)$ & - & $5(25)$ & 2.5 & 0.383 \\
\hline 6 & $\begin{array}{l}\text { Subsidy on big machinery is more beneficial } \\
\text { for large farmers than small and marginal } \\
\text { farmers }\end{array}$ & $18(90)$ & $2(10)$ & - & 2.9 & $17(85)$ & $3(15)$ & - & 2.85 & 0.467 \\
\hline 7 & $\begin{array}{l}\text { Higher percentage of allocated funds for } \\
\text { subsidy is for machines than inputs like } \\
\text { seeds, fertilizers, pesticides etc. }\end{array}$ & $17(85)$ & $3(15)$ & - & 2.85 & $15(75)$ & $5(25)$ & - & 2.75 & 0.777 \\
\hline 8 & $\begin{array}{l}\text { Subsidies on the purchase of machinery are } \\
\text { a better option for the farmer as compared to } \\
\text { their custom hiring. }\end{array}$ & $2(10)$ & $2(10)$ & $16(80)$ & 1.3 & $2(10)$ & $4(20)$ & $14(70)$ & 1.4 & 0.472 \\
\hline 9 & $\begin{array}{l}\text { Reduction in agricultural input subsidies on } \\
\text { wheat and rice will force farmers to diversify } \\
\text { production in order to reduce risk and } \\
\text { increase profit }\end{array}$ & $3(15)$ & $2(10)$ & $15(75)$ & 1.4 & $3(15)$ & - & $17(85)$ & 1.3 & 0.425 \\
\hline 10 & $\begin{array}{c}\text { Subsidies are not biased towards large } \\
\text { farmers. }\end{array}$ & - & - & $20(100)$ & 1 & $6(30)$ & $6(30)$ & $8(40)$ & 1.9 & $4.722^{* *}$ \\
\hline 11 & $\begin{array}{l}\text { The subsidy should be discontinued or } \\
\text { tapered after it has become cost effective. }\end{array}$ & $18(90)$ & $2(10)$ & - & 2.9 & $17(85)$ & $3(15)$ & - & 2.85 & 0.467 \\
\hline 12 & $\begin{array}{l}\text { Subsidies are a burden on country's } \\
\text { economy. }\end{array}$ & $12(60)$ & $3(15)$ & $5(25)$ & 2.35 & $11(55)$ & $5(25)$ & $4(20)$ & 2.35 & 0 \\
\hline 13 & Subsidies should be discontinued. & $4(20)$ & $2(10)$ & $14(70)$ & 1.5 & $5(25)$ & $2(10)$ & $13(65)$ & 1.6 & 0.369 \\
\hline
\end{tabular}

**Significant at 0.01 level, $f=$ frequency, $A=$ Agree, $N=$ Neutral, $D=$ Disagree, $M S=$ Mean Score

Source: Field Survey.

a better option for the farmer as compared to their custom hiring.

Majority of the economists (90\%) and extension personnel $(85 \%)$ opined that the subsidies were responsible for making producers more dependent on the government and that the subsidies should be discontinued or tapered they have become cost effective. More than two-third of the economists $(85 \%)$ and extension personnel $(80 \%)$ agreed that subsidies helped to increase production while a same percentage of economists and 75 per cent of the extension personnel agreed that the maximum percentage of funds under subsidies were allocated for agricultural machinery rather than seeds, fertilisers, plant protection materials and micro irrigation units. More than two-third of economists (75\%) and all the extension personnel agreed that subsidies on big agricultural machinery were more beneficial for large farmers rather than small and marginal farmers. 
More than two-third of extension personnel $(75 \%)$ and 55 per cent of economists agreed that the farmers should be ready to pay the bills for electricity if uninterrupted and timely supply of electricity is provided for the farming purposes. Whereas 25 per cent of extension personnel and 15 per cent of economists were in disagreement with this issue, 30 per cent of economists were neutral to this statement.

Less than two-third of economists and more than 50 per cent of the extension personnel (55\%) felt that subsidies are a burden on country's economy while 25 per cent of economists were in disagreed with it. More than two-third of the economists $(70 \%)$ and a little less than two-third of extension personnel (65\%) disagreed that the subsidies should be discontinued. The reason that both the section gave was that subsidies were a support to bridge the gap of the salary received by a service person and earnings of a farmer. They also mentioned that these subsidies were a support to livelihood of the small and marginal farmers to protect them from large farmers in the developing and developed countries and it was very justified to give subsidies to those person who are providing food to every other.

\section{Opinion of the economists and extension personnel on the areas where subsidy should be given or withdrawn}

The data presented in Table 2 revealed that all of the economists and extension personnel were in favour of subsidies to be given in the areas of credit, price (MSP), infrastructure and export. The economists and extension personnel emphasised that these areas would help in increasing the public investment to build infrastructure for upliftment of agriculture.

Regarding the area of seeds, all the extension personnel and 85 per cent of economists were in favour of subsidies to be given to seeds as it is the basic input of subsidies and they emphasised that subsidies should also be provided more on seeds of non-traditional crops. Similar to farmers, 75 per cent of economists and 80 per cent of extension personnel supported the withdrawal of plant protection subsidies. More than two-third of the economists $(90 \%)$ and extension personnel (75\%) supported that subsidy should be given on micro-irrigation units to promote water conservation and improve the depleting ground water table. Around 85 per cent of economists and 90 per cent of extension personnel rooted for the removal of power subsidy on the same grounds as mentioned by the farmers. They also mentioned that the low agricultural and rural sector revenues have led state electricity utilities to view agricultural consumers as a liability and provide them with low-quality electricity.

More than two-third of economists (80\%) and extension personnel (70\%) were in favour of fertiliser subsidy, but they also recommended a change in policy where the subsidy on urea to be decontrolled which would help in bringing down the overuse of urea which is available at cheaper subsidized rate. Majority of the economists (90\%) and extension personnel (85\%) were in the favour of removal of machinery subsidy to curb down the over-mechanization of the agriculture sector and indebtness of small and marginal farmers.

\section{Preferred criteria of economists and extension personnel for disbursement of agricultural subsidies}

A perusal of data in Table 3 revealed that all the economists as well as the extension personnel were in favour of land holdings, farmers groups and crops being grown by farmers as the major criteria for the disbursement of subsidies as the government can ensure food security of the nation as well as the adoption of a new crop can be facilitated thus breaking the mono-cropping syndrome of wheatrice continuum. Majority of the economists (85\%) and extension personnel (90\%) were in consensus on number of times a person has availed subsidy to be fixed. Regarding the time gap to be fixed and maintained between one subsidy and the other 80 per cent of economists and 85 per cent of the extension personnel preferred this criteria while one subsidy per household per season to be the criteria for the disbursement of the subsidies was preferred by 90 per cent and 100 per cent of the economists and extension personnel respectively so that the small and marginal farmers can get an equal chance of receiving the benefits of the subsidy program and that the dominance of large farmers in the subsidy program could be curbed down. This will also lower down the repetition of farmers under various subsidies. 
Table 2: Distribution of economists and extension personnel regarding their opinion on areas where subsidy should be given/withdrawn

\begin{tabular}{|c|c|c|c|c|c|c|c|c|}
\hline \multirow[b]{2}{*}{ S1. No. } & \multirow[b]{2}{*}{ Area of Subsidy } & \multicolumn{3}{|c|}{ Economists $(n=20)$} & \multicolumn{3}{|c|}{ Extension Personnel $(\mathrm{n}=20)$} & \multirow[b]{2}{*}{$\mathrm{t}$-value } \\
\hline & & $\begin{array}{c}\text { G } \\
f(\%)\end{array}$ & $\begin{array}{c}W \\
\text { f (\%) }\end{array}$ & MS & $\begin{array}{c}G \\
f(\%)\end{array}$ & $\begin{array}{c}W \\
\text { f (\%) }\end{array}$ & MS & \\
\hline 1 & Power & $3(15)$ & $17(85)$ & 1.15 & $2(10)$ & $18(90)$ & 1.1 & 0.467 \\
\hline 2 & Fertiliser & $16(80)$ & $4(20)$ & 1.8 & $14(70)$ & $6(30)$ & 1.7 & 0.716 \\
\hline 3 & Micro-Irrigation & $17(85)$ & $3(15)$ & 1.85 & $16(80)$ & $4(20)$ & 1.8 & 0.406 \\
\hline 4 & Seed & $20(100)$ & - & 2 & $20(100)$ & - & 2 & 0 \\
\hline 5 & Plant protection & $5(25)$ & $15(75)$ & 1.25 & $4(20)$ & $16(80)$ & 1.2 & 0.369 \\
\hline 6 & Machinery & $2(10)$ & $18(90)$ & 1.1 & $3(15)$ & $17(85)$ & 1.15 & 0.467 \\
\hline 7 & Credit & $20(100)$ & - & 2 & $20(100)$ & - & 2 & 0 \\
\hline 8 & Infrastructure & $20(100)$ & - & 2 & $20(100)$ & - & 2 & 0 \\
\hline 9 & Price (MSP) & $20(100)$ & - & 2 & $20(100)$ & - & 2 & 0 \\
\hline 10 & Export & $20(100)$ & - & 2 & $20(100)$ & - & 2 & 0 \\
\hline
\end{tabular}

$G=$ Given, $W=$ Withdrawn, $N A=$ No Answer.

Source: Field Survey.

Table 3: Distribution of economists and extension personnel according to their preferred criteria for disbursement of agricultural subsidies

\begin{tabular}{|c|c|c|c|c|c|c|c|c|}
\hline \multirow[b]{2}{*}{$\begin{array}{l}\text { S1. } \\
\text { No. }\end{array}$} & \multirow[b]{2}{*}{ Criteria/s } & \multicolumn{3}{|c|}{ Economists $(n=20)$} & \multicolumn{3}{|c|}{ Extension Personnel $(\mathrm{n}=20)$} & \multirow[b]{2}{*}{$t$ - value } \\
\hline & & $\begin{array}{c}A \\
f(\%)\end{array}$ & $\begin{array}{c}D \\
f(\%)\end{array}$ & MS & $\begin{array}{c}A \\
f(\%)\end{array}$ & $\begin{array}{c}D \\
f(\%)\end{array}$ & MS & \\
\hline 1 & Caste & $5(25)$ & $15(75)$ & 1.25 & $4(20)$ & $16(80)$ & 1.2 & 0.369 \\
\hline 2 & Land holding & $20(100)$ & - & 2 & $20(100)$ & - & 2 & 0 \\
\hline 3 & Farmers groups & $20(100)$ & - & 2 & $20(100)$ & - & 2 & 0 \\
\hline 4 & Integrated Farming System & $15(75)$ & $5(25)$ & 1.75 & $14(70)$ & $6(30)$ & 1.7 & 0.345 \\
\hline 5 & Crops grown & $20(100)$ & - & 2 & $20(100)$ & - & 2 & 0 \\
\hline 6 & $\begin{array}{l}\text { Number of times a person can } \\
\text { avail the subsidy to be fixed }\end{array}$ & $17(85)$ & $3(15)$ & 1.85 & $18(90)$ & $2(10)$ & 1.9 & 0.467 \\
\hline 7 & $\begin{array}{c}\text { Time gap b/w one subsidy and } \\
\text { the next }\end{array}$ & $16(80)$ & $4(20)$ & 1.8 & $17(85)$ & $3(15)$ & 1.85 & 0.406 \\
\hline 8 & One subsidy/ household/ season & $18(90)$ & $2(10)$ & 1.9 & $20(100)$ & - & 2 & 1.455 \\
\hline
\end{tabular}

A = Agree, $D=$ Disagree.

Source: Field Survey.

More than two-third of the economists (75\%) and extension personnel (70\%) agreed on the integrated farming system to be the criteria for disbursement of subsidies. The economists and extension personnel reasoned that establishing integrated farming system as the criteria would compel farmers of all section to adapt it and thus facilitate the diversification of the agriculture sector at every level. While 75 per cent of problem economists and 80 per cent of extension personnel disagreed upon caste being as the criteria for disbursement of the subsidies.
Although a small percentage of economists and extension personnel insisted that the caste should be taken into consideration for only those farmer who are really needy/weaker. Overall, the economists and extension personnel recommended for subsidies to be given in every area irrespective of the criteria followed for disbursement of agriculture subsidies but with a targeted distribution towards the needy section of farmers' i.e. small and marginal farmers and within limits to large farmers to boost them to remain in agriculture sector. 


\section{CONCLUSION}

The agriculture subsidies are integral part of the farmers in India. The agriculture subsidies play vital role in agriculture sector in every country. Every year Government of India spends lot of money in various agriculture subsidies for growth of agriculture sector. One of the important reasons for deceleration in agricultural growth has been declining levels of investment in agriculture and allied sectors, particularly public investment. A key reason for declining public investment in agriculture has been ever increasing agricultural subsidies. Food and agricultural subsidies are far greater than public investment in agriculture and allied sectors. In addition there has been deterioration in quality of institutions/organizations providing inputs and services such as credit, seeds, technology, extension, etc. Investment in public goods such as agricultural research and extension, rural roads, and irrigation typically produce far greater returns than spending on input subsidies. Therefore, a reorientation of public spending from input subsidies and increased investment in public goods is likely to accelerate agricultural growth. To decrease the fiscal burden on the government pertaining to agricultural subsidies, public sector investment in development of agriculture and rural infrastructure and agricultural research needs to be boosted by the government. The funds allocated for the subsidies on machinery should be minimized and channelized towards increasing quantity of other inputs such as seeds, fertilizers and plant protection materials for a wider coverage of small and marginal farmers. Agriculture subsidies needs to be well targeted. The criteria of disbursement of agricultural subsidies should be stringent based on the farmers' operational land holdings for ensuring maximum coverage of small and marginal farmers. Disbursement of subsidies on the basis of caste should also ensure the availability of these subsidies to the weaker sections of those caste. In the end, agricultural subsidies on various inputs can be discontinued in a phased manner once they become cost-effective to avoid fiscal burden on government and shifted required areas in agriculture.

\section{REFERENCES}

Fan, S., Gulati, A. \& Thorat, S. 2007. Investment, subsidies, and pro-poor growth in rural India. IFPI discussion paper. Pp 1-38. Development Strategy and Governance Division, New Delhi.

Government of India. 2011. Interim report on the task force on direct transfer of subsidies on kerosene, LPG and fertiliser. Ministry of petroleum and Natural gas, government of India, New Delhi.

Gulati, A. \& Narayanan, S. 2003. The subsidy syndrome in Indian agriculture. Oxford University Press, New Delhi.

Kaur, R. 2012. Agriculture subsidies in Punjab: An analysis. Doctoral thesis, Punjabi University, Patiala, India.

Mahadeva, M. 2004. Agricultural input subsidies in Karnataka: quantum of subsidies to SC/ST farmers. Agricultural Development and Rural Transformation Unit, Institute for Social and Economic Change. Nagarabhavi, Bangalore.

Sharma, V.J. \& Thaker, H. 2009. Fertilizer Subsidy in India: Who are the Beneficiaries? Research and Publications, Indian Institute of Management, Ahmedabad, India.

Sinha, S.P. \& Prasad, J. 1982. Impact of farm subsidies on production, income and employment in Bihar: A case study in Masahara Block, District: Muzaffarpur, Bihar. Indian Journal of Agricultural Economics, 37: 277-81.

Swaminathan, B., Chinnadurai, M. \& Siva Balan, K.C. 2013. What has been sown has not been harvested: The curious case of farm subsidies in India. International Journal of Research in Commerce, Economics and Management, 3: 69-71. 